\title{
Vascular Disrupting Agent BNC105
}

National Cancer Institute

\section{Source}

National Cancer Institute. Vascular Disrupting Agent BNC105. NCI Thesaurus. Code C162343.

A vascular disrupting agent (VDA), with potential anti-vascular and antineoplastic activities. Upon administration, vascular disrupting agent BNC105 binds to tubulin and inhibits its polymerization, which results in a blockage of mitotic spindle formation, cell cycle arrest, and disruption of the tumor vasculature. This deprives tumor cells of nutrients and results in tumor cell apoptosis. In addition to its VDA activity, this agent has a direct cytotoxic effect on tumor cells by inhibiting tubulin polymerization. 